\begin{abstract}
Література:
1. Ma Y, Diao B, Lv X, et al. Epidemiological, clinical, and immunological features of a cluster of COVID-19-contracted hemodialysis patients. Kidney Int Rep. 2020;5(8):1333-1341.

2. Valeri AM, Robbins-Juarez SY, Stevens JS, et al. Presentation and outcomes of patients with ESKD and COVID-19. J Am Soc Nephrol. 2020;31(7):1409-1415.
\end{abstract}

DOI https://doi.org/10.30525/978-9934-26-182-4-18

\title{
РАЦІОНАЛЬНЕ ЗАСТОСУВАННЯ ТОПІЧНИХ КОРТИКОСТЕРОЇДІВ ДЛЯ ЗОВНІШНЬОЇ ТЕРАПІЇ ПСОРІАЗУ
}

\author{
Рябова О. О. \\ кандидат медичних наук, доиент, \\ дочент закладу вищої освіти кафедри фармакології \\ та фармакотерапії \\ Національний фармачевтичний університет \\ Кашута В. $\mathbf{\epsilon}$. \\ кандидат медичних наук, доиент, \\ доцент закладу вищої освіти кафедри фармакології \\ та фармакотерапії \\ Наџіональний фармацевтичний університет \\ м. Харків, Украӥна
}

На сьогоднішній день псоріаз $\epsilon$ актуальною медико-соціальною проблемою. Поширеність захворюваності на псоріаз серед осіб будь-якого віку, тривалі рецидиви дерматозу, повна або часткова втрата працездатності, високі рівні інвалідизації, що супроводжуються соціальнопсихологічною дезадаптацією пацієнтів, обумовлюють актуальність проблеми псоріазу [1, с.10].

Псоріаз розглядають як полісистемне, генетично детерміноване, хронічне, рецидивуюче захворювання організму багатофакторної природи, що характеризується імунозалежним запаленням, доброякісною гіперпроліферацією епідермальних клітин з аномальною їх диференціацією та супроводжується папуло-сквамозними висипаннями, стадійністю, 
тяжкістю перебігу та можливим залученням до патологічного процесу внутрішніх органів та опорно-рухового апарату [1, с. 10].

Велике значення в фармакотерапії псоріазу має зовнішня (топічна) терапія через можливість безпосереднього впливу на уражені ділянки шкіри, що значно поліпшує результати лікування, а при легкому перебігу дерматозу дає можливість зовсім уникнути застосування засобів для системної терапії [1, с. 29].

Значне місце серед засобів топічної терапії, що застосовуються при псоріазі, посідають саме топічні кортикостероїди (ТКС). Це пов’язано з їх потужною протизапальною, імуносупресивною, протиалергічною та антипроліферативною діями. Враховуючи, що на сьогоднішній день при псоріазі відбувається генетично детермінований розвиток імунного запалення в шкірі, застосування ТКС для зовнішній терапії псоріазу стає патогенетично обгрунтованим. Впливаючи на різні ланки патогенезу дерматозу, ТКС забезпечує швидкий терапевтичний ефект [2, с. 436].

3 огляду на сучасні іноземні та вітчизняні настанови щодо терапії псоріазу, а також власний досвід лікування хворих на псоріаз нами було розроблено рекомендації щодо раціонального та безпечного застосування ТКС у хворих на псоріаз. За сучасними рекомендаціями щодо раціональної фармакотерапії псоріазу при застосуванні ТКС слід враховувати потужність дії (клас активності) препарату, лікарську форму, вік пацієнта, тяжкість дерматозу та обирати оптимальні режими аплікацій для хворих на псоріаз [2, с. 436].

Як правило, для зовнішнього лікування псоріазу рекомендовано обирати ТКС надзвичайно високої активності (IV клас), такі, як клобетазолу пропіонат, та високої активності (III клас), а саме, бетаметазону валерат $(0,1 \%)$, гідрокортикозону бутират, мометазону фуроат тощо. ТКС IV класу активності найчастіше використовували для аплікацій на ділянки шкіри 3 щільним роговим шаром, зокрема долоні та підошви. При застосуванні ТКС, що містять фтор, найчастіше виникають побічні ефекти, як локальні, так і системні, тому не рекомендовано застосовувати сильні фторовані ТКС на ділянках, де тонка шкіра, а саме, на будь-які ділянки шкіри у дітей, на шкіру обличчя та шиї, крупних складок. Кращий профіль безпеки та достатньо високу силу дії мають галогенізовані нефторовані ТКС, зокрема мометазону фуроат, що містить атом хлору, та ТКС, що не містять галоїдів, такі як метилпреднізолону ацепонат та гідрокортизону бутират. За власним досвідом, застосування ТКС на шкіру обличчя та шиї у хворих на псоріаз намагалися уникати, замінюючи їх на топічні інгібітори кальциневрину, зокрема пімекролімус. 
У разі наявності вираженого гіперкератозу в місцях аплікації ТКС застосовували фіксовані комбінації ТКС 3 кератолітичним засобом (саліциловою кислотою, сечовиною), а після очищення шкіри від лусок переходили на монотерапію ТКС.

При виборі лікарської форми ТКС (мазь, крем, лосьйон) слід враховувати ступінь проникнення препарату в шкіру. ТКС у вигляді лосьйону застосовували у разі локалізації дерматозу на волосяній частині голови, у вигляді крему - при гострому запаленні та наявності дерматозу в складках шкіри, у формі мазі - при підгострому та хронічному запаленні в шкіри.

При застосуванні ТКС слід дотримуватися певного дозування. Для дозування м'якої форми ТКС використовують умовну одиницю - одиницю кінчика пальця (ОКП), що дорівнює приблизно 0,5 г ТКС. Для безпечного застосування ТКС, зменшення частоти виникнення побічних ефектів при поширеному патологічному шкірному процесі не рекомендували хворим перевищувати кількість ТКС при аплікаціях на певні ділянки тіла: тулуб - 7 ОКП, обличчя, шию - 2,5 ОКП, одна рука - 3 ОКП, одна кисть - 0,5 ОКП, одна нога - 6 ОКП, одна стопа - 2 ОКП.

Для стабілізації шкірного процесу хворим на псоріаз аплікації ТКС були рекомендовані 1-2 рази на день у вигляді безперервного режиму застосування, по досягненню стабілізації процесу (але тривалістю не більше 2-4 тижнів) переходили на інтермітуючий режим застосування ТКС. 3 метою зменшення частоти побічних ефектів у разі необхідності більш тривалого застосування ТКС, або при великій площі дерматозу рекомендували хворим дотримуватися режимів ступінчастої та штрихової аплікації. Для догляду за шкірою під час лікування всім хворим на псоріаз рекомендували застосовувати емолієнти.

Таким чином, раціональне застосування ТКС у хворих на псоріаз дозволить досягти найшвидшого терапевтичного ефекту та зменшить частоту виникнення місцевих та системних побічних ефектів.

\section{Література:}

1. Псоріаз, включаючи псоріатичні артропатії. Уніфікований клінічний протокол первинної, вторинної (спеціалізованої), третинної (високоспеціалізованої) медичної допомоги : наказ МОЗ України від 20.11.15 № 762. Реєстр медико-технологічних документів. К., 2015. 40 с.

2. Guidelines of care for the management and treatment of psoriasis with topical therapy and alternative medicine modalities for psoriasis severity measures. Elmets C. A., Korman N. J., Prater E. F. et al. J. Am. Acad. Dermatol. 2021. Vol. 84, T.2. P. 432-470. 